Société d'histoire de la révolution de 1848 et des

révolutions du XIXe siècle

16 | 1998

1848. Un modèle politique à l'épreuve

Maurice et La Réunion : deux îles de l'océan Indien face à la France de 1848

Bernard Lejeune and Évelyne Lejeune-Resnick

(2) OpenEdition

Journals

Electronic version

URL: http://journals.openedition.org/rh19/131

DOI: $10.4000 /$ rh19.131

ISSN: $1777-5329$

Publisher

La Société de 1848

Printed version

Date of publication: 1 June 1998

ISSN: 1265-1354

Electronic reference

Bernard Lejeune and Évelyne Lejeune-Resnick, « Maurice et La Réunion : deux îles de l'océan Indien face à la France de 1848 », Revue d'histoire du XIXe siècle [Online], 16| 1998, Online since 10 September 2008, connection on 19 April 2019. URL : http://journals.openedition.org/rh19/131 ; DOI : 10.4000/ rh19.131

This text was automatically generated on 19 April 2019

Tous droits réservés 


\title{
Maurice et La Réunion : deux îles de l'océan Indien face à la France de
} 1848

\author{
Bernard Lejeune and Évelyne Lejeune-Resnick
}

\section{ABSTRACTS}

Mauritius and the Reunion, two islands of the Indian Ocean faced with 1848 France. At Mauritius and the Reunion the advent of the Second Republic brought to light the social tensions that were at work in these colonial societies. Mauritius, a French-speaking English colony where slavery had been abolished since 1834, was dominated by white families who hated England. They lived in the memory of 1789 France and hoped that the election of Louis-Napoleon Bonaparte would bring them back into France's bosom even though they didn't really approve of the republican regime. The Reunion, a French colony, was confronted with the abolition of slavery, which became effective in 1848. Slavery went against the political and economics interests of settlers hostile to the republic, in spite of the efforts of the representative sent by Paris. Emancipated slaves were hardly more enthusiastic about the February revolution since their main preoccupations were more about the right to work than the exercise of citizenship

Dans l'île Maurice et celle de la Réunion, l'avènement de la Seconde République met en lumière les tensions sociales à l'œuvre dans ces sociétés coloniales. L'île Maurice, colonie anglaise et francophone où l'esclavage a été aboli depuis 1834, est dominée par des familles blanches, haïssant l'Angleterre, vivant dans le souvenir de la France de 1789 et espérant de l'élection de Louis-Napoléon Bonaparte un retour dans le giron de la France, même si le régime républicain n'a pas vraiment leurs faveurs. La Réunion, colonie française est confrontée à l'abolition de l'esclavage, effective en décembre 1848 , et qui heurte les intérêts politiques et économiques de 
colons hostiles à la république, malgré les efforts du commissaire envoyé par Paris. Les affranchis, ne montrent guère plus d'enthousiasme envers la révolution de février: leurs préoccupations essentielles se portent sur le droit au travail plutôt que sur l'exercice de la citoyenneté.

INDEX

Mots-clés: 1848 , Iles 